\title{
What Should Feminists do about Nature?
}

Bonnie Mann

University of Oregon

Feminists, including this one, have two problems with nature: a special problem which is a historical and political problem, and an ontological problem that we share with everyone else (our metabolism with the earth). My claim is that the first problem is so acute that it tends to make us forget the second. The fundamental division in contemporary feminist thinking can be described as that between feminists who are interested in deconstructing, all the way down, the notion of natural differences between women and men as pre-social, and feminists who are interested in recuperating, re-affirming or asserting some version of originary sexual difference. By returning to Simone de Beauvoir, we find that even at this early moment in contemporary feminist thought a more complex account of nature was already articulated. Beauvoir helps us understand how structures of injustice are parasitically entangled with general features of human existence, even those that seem most "natural." At one founding moment of contemporary feminist thinking, then, deconstructive and descriptive engagements with the question of nature, far from being opposed, are co-necessary features of feminist thought.

"Nature" is the historical millstone hung round the necks of women. It is not the only such stone, but it has been the heaviest and the most securely tied. If we understand feminism to be first a social movement for the emancipation of women, then we recognize that the question of nature has been the central question for feminism because the question of nature is the question of freedom for women.

Contemporary feminist thought finds itself negotiating a divide over the question of nature which is not to be equated with a dispute between continental and analytic philosophical approaches. That dispute has relatively little salience in feminist thought on this question, since the divide over nature is negotiated within these approaches more than between them. This is to say, all feminist thinkers face the question of whether "sexual difference" and "gender difference" are simply ways of talking about the long-term effects of carrying around a very heavy stone, or whether these terms (or the first of them at least) name a site from which meaning is or can be generated that escapes or exceeds the drag of an enormous historical weight. Within the continental tradition, which is the tradition I engage here, it is this question that demarcates the main divisions in contemporary feminist thought, and more importantly, our main challenge as feminist thinkers.

What should feminists do about Nature? I have formulated the question, I admit, in a strangely simplistic way given the sophisticated subtleties of contemporary feminist 
engagements with it. And while simplicity, my reader will assent, has its virtues, it also has its vices. My formulation affirms that there is a problem between feminists and nature (no surprise there), but also implies that nature is the sort of thing that some set of subjects called feminists can do something about, maybe even must do something about. Not only that, but already I am slipping between "nature" in scare quotes and nature standing on its own, from a figure constituted by human minds, hands, institutions, to one that is not reducible to and maybe even only has meaning as distinct from or excessive to human making. It may not please my reader to find that I am determined to continue this sloppy thinking. I will only defend myself here by promising to consider the source of such sloppiness throughout the essay, and by pointing once again to that millstone round our necks. It is a flattened, round stone and has a hole in the center with a chain through it, evidence enough that we are not talking about nature but about "nature," yet it is, after all, a stone. One can imagine that it lay innocently and naturally enough in a meadow or a forest somewhere at some point, its weight quite indifferent to the one who found it and lay claim to it, but who needed precisely that indifferent weight to grind grain and feed himself.

The millstone is, then, evidence not only of historical injustice, but of what Marx, and Arendt following Marx, designated significantly as "our metabolism with the earth." If we are to live at all we have to work on a nature that persistently exceeds, escapes, and resists human making, and unless we are able and willing to do this work or have some other creature, human or beast, we can pay, force or cajole into doing it for us, we sink back into the matter of the earth and feed something else (whether microbe, worm or Service Corporation, Inc. ${ }^{1}$ ). Needless to say, this is a problem that women and men share, and share with every other living thing on the planet. We are ontologically entangled with grain and stone. The notorious ambiguity of the human condition that the existentialists so insisted we pay attention to results from this; we are part of and dependent on a nature that seems to be a vast system of indifferent processes, and yet we must think and act, i.e. deploy our freedom, in relation to it.

Feminists, including this one, have two problems with nature then: a special problem which is a historical and political problem (the millstone round our necks), and an ontological problem that we share with everyone else (our metabolism with the earth). My claim is that the first problem is so acute that it tends to make us forget the second. This results in the 
persistent ghettoization of feminist thinking about nature around the question of sexual difference. Yet, I contend, we can only make sense of the continued efficacy of egregious associations between women and nature if we understand the political problem by means of the ontological problem, i.e. if the problem of sexual difference opens out onto the problem of nature more broadly.

The existentialists, who some are prone to dismiss today as having counted on an overinflated notion of human freedom rooted in Cartesian ontology, were nonetheless the ones who noticed so consistently that humans have a very hard time coming to terms with the fundamental paradox of the human condition, with being nature and yet being the kinds of creatures who experience ourselves at a certain distance from nature. Women aren't, perhaps, as much better at this than men as we once hoped. Beauvoir's account is the classic one:

From the moment [s] he is born, from the instant [s] he is conceived, a [wo]man begins to die; the very movement of life is a steady progression toward the decomposition of the tomb. This ambivalence is at the heart of every individualized organism, but...[wo]man knows it. For [her], this life that makes itself by unmaking itself is not just a natural process; it itself thinks itself. A new paradox is thereby introduced into [wo]man's destiny. As a 'rational animal' and a 'thinking reed,' [s] he frees [her]self from [her] immediate condition yet without destroying it. [She] is part of the world of which [she] is a consciousness. (Beauvoir 2004, 299) ${ }^{2}$

Our ontological condition mandates that we do something about nature because we are irretrievably part of it and irrevocably in need of it, yet not completely immersed in it.

For women this mandate is at least double, ${ }^{3}$ because dominant traditions in the west have consistently tried to overcome the ambiguity of the human relation to nature by making women the natural part of humanity and men the bearers of consciousness and culture. To repeat myself, the trouble feminists have with nature is both specific to women and not specific to women, and we haven't been very good at sorting this out, for some very good reasons. The identification of women with nature, often in the same breath that the human is distinguished from nature, and an obsessive fascination with natural sexual difference which we inherit like a bad debt, are at the heart of the specific cultural legacy that women carry in the 
tradition of western philosophy. The need to justify injustice, to provide an alibi for egregious social hierarchies that organize the parasitic appropriation of women's labor, both reproductive and productive, by men, has been so entangled with efforts to describe what natural sexual difference is, that any attempt to address these differences is inescapably burdened by that history, i.e., it carries with it, to speak like Virginia Woolf for a moment, a certain odor of injustice (Woolf 1938, 50-53). This odor fills the room whenever anyone speaks of sexual difference as natural difference, or originary difference (which seems always to reduce to the same thing), or essential difference (which seems always to reduce to the same thing), and it carries that odor even when the speaker is herself feminist.

If the fundamental division in contemporary feminist thinking can be described as that between feminists who are interested in deconstructing, all the way down, the notion of natural differences between women and men as pre-social, as grounding the social, and feminists who are interested in recuperating, re-affirming or asserting some version of originary sexual difference, most commonly through the use of psychoanalytic explorations of the symbolic which have themselves a strained and strange relation to what we call nature, ${ }^{4}$ then the question of what feminists should do about nature has not been settled. So, on the one hand, certain forms of feminist materialism and feminist poststructuralism do away with nature altogether (Wittig, Guillaumin, Butler); on the other hand, certain forms of psychoanalytic feminism seem to rely obliquely on the natural as the foundation of the symbolic in their insistence on an originary and irreducible sexual difference (Irigaray, Kristeva). I read this division in feminist thinking as a symptom of the difficulty we have enduring two ambiguities: the paradox of the human condition on the one hand, and the tension between our political inheritance of an egregious association between women and nature and our impulse to affirm "the feminine" as an originary source of meaning and value on the other. Contemporary efforts to address the problem are encouraging, though still only in their incipient moment, and still struggling with a tendency to collapse one term into the other, i.e. nature into culture (making everything a question of politics), or culture into nature (where everything is staked on getting our account of nature right, making politics a mere matter of correcting nasty epistemological mistakes). ${ }^{5}$ 


\section{The Legacy and its Contemporary Manifestations}

I want to start by spending a little time thinking about what l've just called our political inheritance of an egregious association between women and nature, even though the topic is so wellstudied at this point, it may seem unnecessary. If we are to understand the intensity of the feminist commitment to a deconstruction of this association, however, it is important that we refresh our memories, while at the same time reminding ourselves that the entanglements of woman/nature that feminists find troublesome are as much a part of our contemporary thinking as they were in the most robust moments of what we call modernity.

In his 1762 treatise on education, Emile, Rousseau reserves his last chapter for the as yet neglected topic of the proper education of women. His basic theory is that the natural differences between women and men must be recognized as having moral force.

This conclusion is evident to the senses; it is in agreement with our experience; and it shows how vain are the disputes as to whether one of the two sexes is superior or whether they are equal-as though each, in fulfilling nature's ends according to its own particular purpose, were thereby less perfect than if it resembled the other more. In what they have in common, they are equal. Where they differ, they are not comparable...In the union of the sexes each contributes equally to the common aim, but not in the same way...one ought to be active and strong, the other passive and weak... Once this principle is established it follows that woman is made specially to please man. If man ought to please her in turn, it is due to a less direct necessity. His merit is in his power; he pleases by the sole fact of his strength. This is not the law of love, I agree. But it is that of nature, prior to love itself. $(1979,358)$

For Rousseau, God has added modesty to nature, in the case of women, and reason to nature in the case of men, so that desire (passive, coquettish desire for the girls and active masterful desire for the boys) doesn't overtake them entirely. Women's education must cultivate modesty while never forgetting what nature has created women for, or as Rousseau puts it at the beginning of the essay, what woman is (357). Kant, writing as if in chorus with Rousseau, and just one year earlier, puts it this way: "The principal object is that the man should become more perfect as a man, and the woman as a wife; that is, that the motives of the sexual 
inclination work according to the hint of nature, still more to ennoble the one and to beautify the qualities of the other" (Kant 1960,95). Both Kant and Rousseau put their faith in natural sexual differences between women and men as a kind of moral guide in education.

Let's fast forward to our own century, and add to these opening citations from the 1760s, a citation from Randy Thornhill and Craig Palmer's MIT Press book, A Natural History of Rape: Biological Bases of Social Coercion, published in 2000.

The ultimate causes of human rape are clearly to be found in the distinctive evolution of male and female sexuality. The evidence demonstrates that rape has evolved as a response to the evolved psychological mechanisms regulating female sexuality, which enabled women to discriminate among potential sex partners. If human females had been selected to be willing to mate with any male under any circumstances, rape would not occur. On the other hand, if human males had been selected to be sexually attracted to only certain females under certain limited circumstances, rape would be far less frequent. Indeed, if human males had been selected to desire sexual intercourse only with females who showed unmistakable willingness to copulate with them, rape would be an impossibility. Human rape exists because selection did not favor these types of adaptations. (Thornhill and Palmer 2000, 84)

The authors of this book explain not only rape, but sexual difference itself ${ }^{6}$, why women suffer psychological trauma from rape; demographic patterns in rape, why rape occurs more often in war, why husbands don't believe their wives when they say they've been raped, and why women lie about being raped; all as ultimately caused by evolutionary processes of genetic selection.

Having lost God as the source of both nature and those aspects of human character that keep a check on nature, their position is the currently popular genetic fundamentalist one (what Kaplan and Rogers call "gene worship") ${ }^{7}$ : for them, learning, culture and even consciousness are all aspects of "our evolved biology" (Thornhill and Craig 2000, 29). The social sciences (and feminism as a movement seems to belong among the social sciences for these authors) have failed to help us understand how to prevent rape because they have failed to understand what rape really is, an evolutionary adaptation or at least a by-product of an evolutionary adaptation. 
Cultural explanations for male sexual aggression fail because they fail to understand that culture, too, is nature, a complex set of adaptations; which is to say that culture is also biology. Social scientists fail to learn from the biological sciences in their evolutionary, endocrinological, or neuro-biological manifestations, because they, not the biological scientists, are prone to the naturalistic fallacy of Rousseau and Kant, assuming that if something exists naturally, then it also provides a kind of moral prescription for human behavior. ${ }^{8}$

Yet evolutionary biologists today are humble about the connection between biology and moral prescriptions, Thornhill and Palmer claim, in a way that Kant and Rousseau were not. They take great pains, the authors tell us, to explain to the social scientists that evolutionary biology does not amount to biological determinism. They state, regarding their own work, that there is no connection here between "what is biologically or naturally selected and what is morally right" (Thornhill and Palmer 2000, 5), and elsewhere, "science has nothing to say about what is right or wrong in the ethical sense. Biology provides understanding, not justification, of human behavior" (199). This understanding, of course, will inform what we decide to do about the problem of rape, but in a purely pragmatic rather than morally prescriptive way: chaperoning is mentioned favorably at one point, as is a distant (for the authors) cultural context in which folks simply assume that an unrelated man who encounters a reproductively viable woman in an isolated area will certainly rape her and so efforts are made to eliminate the possibility of such encounters (by keeping the men home? Thornhill and Palmer don't say) (I85186).

On the one hand we might like to celebrate this laudatory reformation of science, biology's new humility about nature's role in the domain of the moral. On the other hand, the odor of injustice hangs about the room, and feminist suspicions fasten on the fact that this is an extremely ahistorical perspective on what biology is. We are tempted to point to the at least 2000 years of history in the west, in which biological observation and science have been used precisely for justificatory purposes, not only by scientists, of course, but by philosophers and politicians, judges and doctors, teen-age boys desperate to sew their so-called wild oats and husbands seeking to reassert their head-of-household authority over unruly wives. Classic examples come to mind, like the scientific discovery that women lacked the region of the brain known as "the intellect," which was a key bit of evidence used to deny women access to higher 
education. The craniologist G. LeBon wrote in 1879, "In the most intelligent races, as among the Parisians, there is a large number of women whose brains are closer in size to those of gorillas than to the most developed male brains. This inferiority is so obvious that no one can contest it for a moment" (cited in Rogers 200I, 6). We could give myriad contemporary examples of biological sciences justifying all kinds of things that seem to inhabit the sphere of the ethical and the political, from the signing or refusal to sign international treaties to curtail the disruption of the earth's climate to performing invasive, irreversible surgery resulting in permanent loss of sexual sensation on healthy infants whose genitals don't meet the prevailing criteria for normalcy.

\section{The "Inaugural Move" of Contemporary Feminism}

No wonder, then, that feminism is known by reputation to be the movement founded in a turn away from what humans call "nature." "The inaugural move of feminism," writes Kate Soper, "in fact, was the challenge it delivered to the presumed 'naturality' of male supremacy... Feminism, as it were, gets off the ground through a deconstructive move whose effect is to expose the discursive 'eternizing' function of 'nature' in endowing with the seal of necessity what in reality is a matter of convention" $(1995,121)$. We find the beginnings of this move, even at the time of Kant and Rousseau, in the work of their contemporary, Mary Wollstonecraft. "Men, in general" she writes, "seem to employ their reason to justify prejudices, which they have imbibed, they can scarcely trace how, rather than to root them out" (Wollstonecraft 1975, 92). "The word masculine is only a bugbear," she says, a boogeyman invented to keep women convinced of the natural superiority of men (83).

This account of feminist history would put feminism squarely in the camp of what Soper calls the "nature-skeptics," and with good reason. But I want to draw a little closer attention to Soper's claim that the "inaugural move" of feminism is a deconstructive one directed at "nature" and its discursive deployments. Not only are there multiple examples, from the inception of contemporary feminist thought, of thinkers who are clearly not nature-skeptics (Shulamith Firestone is an oft-cited example, but we could also include Mary Daly, Susan Griffin, and much ecofeminist thought on a quick list just on this side of the Atlantic), but as l've already 
noted, the contemporary divide in continental feminism, and efforts to defend or criticize one side or the other, hangs precisely on this point.

What is the inaugural move of feminism, after all? When did it occur? Who made that move? Soper doesn't say much at all about what she means by this phrase nor about what the process of authorization is that turns a particular moment into an inaugural one. But if feminism has an inaugural move and it can be characterized in the way she says it can, it is important that we engage the question of what that move is more thoroughly.

Hannah Arendt gives us some guidance here, concerned as she was with the meaning of what she called "founding moments." Arendt anchors her discussion of "founding" in the history of Rome, and tells us that the very concept of authority arises in Rome. "At the heart of Roman politics," she writes, "stands the conviction of the sacredness of foundation, in the sense that once something has been founded it remains binding for all future generations" (Arendt 1954, 120). A founding is "the central, decisive, unrepeatable beginning...a unique event" $(|2|)$. The very point of engaging in politics, for the Romans, is "to preserve the foundation of the city of Rome" (I20). The word "authority" derives from a Latin verb which means "to augment." "What those in authority constantly augment," Arendt claims, "is the foundation" $(121-122)$. The authority that those in power have is rooted in the past, in the “sacred beginning of Roman history" (123). Those in authority do not have power, or need it, nor do they need violence. One only needs power or violence once authority breaks down.

Arendt tells us that the only place in contemporary life where we retain this notion of a founding and the authority that emerges from it is in our conception of revolution (136). In other words, radical political upheaval seems to need this notion of a founding as a reference point in the past, even if the very recent past, which serves as a kind of stabilizing touchstone in the present and a guide into the future. Soper talks about the "inaugural moment" of contemporary feminism as having precisely that kind of authoritative force, the authoritative force of a new and almost sacred beginning. Insofar as feminism constitutes a radical political and conceptual upheaval, and that conceptual upheaval is rooted in a founding moment which denaturalizes and historicizes nature, then it will be legitimate to speak of this inaugural move of feminism as having authoritative force. 
Of course, and Arendt is aware of this, the notion of a "founding" is in no way a frozen notion and the practice of an appeal to a "founding" is in no way a frozen practice. We are constantly in the process of identifying and interpreting the founding moment (a process which is by no means innocent of material interests), of negotiating appeals to that moment, of renewing the founding, we might say, or of relevancing the founding in the context of our contemporary concerns. When Soper appeals to the inaugural moment of feminism and characterizes that appeal, she is claiming relevance and authority for a certain interpretation of the founding. And in the face of contemporary work like that of Thornhill and Palmer, there is no reason to suggest that this authoritative force should not be maintained. ${ }^{9}$

If we are to identify the founding moment for contemporary feminism in the west, there are various contested ways to do that, but in philosophy a clear candidate for the title of "inaugural event" is the publication of Simone de Beauvoir's The Second Sex in 1949 in France. Certainly, Soper's characterization of the founding as the denaturalizing of the natural seems to match the substance of Beauvoir's conceptual and philosophical upheaval of the tradition; the famous first sentence of volume II, "One is not born, but rather becomes a woman," is perhaps the most often quoted line in the history of all feminist thought, and is consistently read as a manifesto against the belief in the social significance of natural sexual difference (1989, Eng. 267; Fr. vol. 2, 13)..$^{10}$ Beauvoir insists that the work of "legislators, priests, philosophers, writers, and scientists" “conceals a desire for self-justification” (Eng. xxviii-xxix; Fr. Vol. I, 25) under the guise of nature. She devotes an entire chapter to the search for a justification of the oppression of women in biology, considering the evidence that is presented in the science of her time, she notes that "It would be foolhardy indeed to deduce from such evidence that woman's place is in the home-but there are foolhardy men” (Eng. I3; Fr. vol. I, 49), and she goes on to name several. At the end of the chapter she makes clear that she considers the facts or "givens" of biology "insufficient for setting up a hierarchy of the sexes; they fail to explain why woman is the Other; they do not condemn her to remain in this subordinate role forever" (Eng. 32-33; Fr. vol. I, 73). "All these dissertations," she notes, "which mingle a vague naturalism with a still more vague ethics or aesthetics are pure verbiage... man is not a natural species: he is a historical idea. Woman is not a completed reality, but rather a becoming... when we have to do with a being whose nature is transcendent action, we can 
never close the books" (Eng. 33-34; Fr. vol. I, 75). In themselves, the givens of biology "have no significance," Beauvoir says; biology is an abstract science, since physiological facts take on meaning only in the context of human interpretation: "nature has reality for him only to the extent that it is involved in his activity," (Eng. 35; Fr. vol. I, 76) and "it is not upon physiology that values can be based; rather, the givens of biology take on the values that the existent bestows upon them," (Eng. 36; Fr. vol. I, 78) and "society alone is the arbiter" of these meanings (Eng. 35; Fr. vol. I, 76). And finally, "Biology is not enough to give an answer to the question that is before us: why is woman the Other?" (Eng. 37; Fr. vol. I, 79). Here Soper's account of the inaugural moment in western feminism seems to be born out in Beauvoir's work.

\section{Relevancing the Founding}

It is no surprise, then, that the champions of sexual difference in France have not, for the most part, been champions of Beauvoir. Beauvoir distanced herself from this tendency explicitly, "I don't believe that there are qualities, values, ways of life specifically feminine, this would amount to admitting the existence of a feminine nature, i.e. adhering to a myth men have invented to lock women into their condition of oppression” (Beauvoir 1975, 508; 1972, 508). On the other hand, those French feminists who claim that sexual difference is itself an effect of social power have also claimed Beauvoir. Significantly, these radically constructivist accounts do not rely, as they do initially in English speaking contexts, on a distinction between sex and gender. In English-speaking contexts, there is still a tendency to ritualistically credit Beauvoir with inventing the distinction between sex and gender that became so significant in AngloAmerican feminist's constructivist accounts of "gender difference," even after much dispute of this point by francophone feminist critics.

Elsewhere, however, Beauvoir herself has been interpreted differently. One strand of Beauvoir criticism claims that she is herself an essentialist, who firmly roots the oppression of women in female bodily differences from men. ${ }^{11}$ Women's reproductive capacities and bodily morphology entail a distinct relation to the species, to time and to space, which are at the heart of women's Otherness from men. This is a biology that is pre-social and heavy-handedly determinative of existential possibilities. These critics point out that for Beauvoir, it is only by 
transcending the realm of female biology (and this transcendence is a newly emergent historical possibility), that women can escape enslavement to the species and enjoy the freedom that men reach more naturally. Here "transcendence" is read as an absolute overcoming or leaving behind of the distinct femaleness of a woman's body that bespeaks a deep devaluation of what is overcome. $^{12}$ Beauvoir's notorious warnings about motherhood and childrearing are read as mandating that women eschew these natural capacities in favor of transcendent (on this interpretation masculine) action. Beauvoir must devalue female biology because she sees it as so negatively determinative of female possibilities.

These disparate readings of Beauvoir are, as other critics have noted, symptomatic of the very problem she is so careful to spell out even in her early work.

As long as there have been men who live, they have all experienced this tragic ambiguity of their condition, but as long as there have been philosophers who think, most of them have tried to mask it. They have striven to reduce mind to matter, to absorb matter into mind, or merge them together within a single substance. Those who accepted the dualism established a hierarchy between the body and the soul that allowed the part of oneself that could not be saved to be considered as negligible. (2004, 290)

In other words, the paradox of immanence and transcendence can neither be eluded nor resolved, it must be suffered. ${ }^{13}$ Beauvoir's work is subject to opposing misinterpretations because our tendency is to want to flee the paradox rather than endure it. Beauvoir's insistence on the irresolvability of our ambiguous relation with nature is unnerving because she affirms that nature is the necessary ground of, indifferent to, excessive of and significant in human endeavors all at the same time. She seems to contradict herself from sentence to sentence because she keeps moving between the two poles of the paradox. ${ }^{14}$

Beauvoir gives an account of a relation between "woman" and "nature" that is not causal in the usual sense. In fact, her seemingly contradictory statements about nature begin to unravel the structure of causality that is the skeletal base on which debates about sexual difference, and so much else, usually hang. In patriarchal accounts nature causes social power differences between men and women. In feminist "denaturalizing” accounts, material and political interests or discursive formations act causally on material bodies to constrain, shape or constitute them 
as sexed. In feminist "renaturalizing" accounts women's bodily differences are backgrounded causes for symbolic formations that are potentially generative of powerful positive meanings for sexual difference. In Beauvoir's phenomenological description of what it means to be a woman, on the other hand, the very force and directionality of causality is not eliminated but diffracted; we are no longer dealing with linear causal chains but with entanglements. ${ }^{15}$

Perhaps the best example to illustrate this point is Beauvoir's continual return to the theme of temporality in her descriptions of women's situation. Even as she dismisses efforts to explain women's social situation by reference to biology, as if biological sexual differences directly cause social hierarchies, and even as she refutes the scientists' pet idea that there is an essential passivity in the biology of the female complemented by an essential activity in the biology of the male, Beauvoir herself takes note of a temporal feature of mammalian biological existence that she finds significant in giving an account of social hierarchies between women and men. "In higher forms of life, reproduction becomes the creation of discrete organisms; it takes on a double face: maintenance of the species and creation of new individuals; this innovating aspect becomes the more unmistakable as the singularity of the individual becomes pronounced. It is striking then that these two essential elements, perpetuation and creation, divide themselves" (Eng. 19, Fr. Vol. I, 56, translation amended). And further: "It is in the mammals that life takes its most complex forms and individualizes itself most concretely. There the division of the two vital moments: maintenance and creation, realizes itself in a definitive way in the separation of the sexes" (Eng. 20, Fr.Vol. I, 58, translation amended). The separation of maintenance and creation is a distinction drawn in time, or better, in the shape of time. Time has two faces, in human life. "To maintain is to deny the scattering of instants...to create is to mark out from temporal unity in general an irreducible, separate present" (Eng. 25, Fr. Vol. I, 63 translation amended). There is no strict division here, but each face of time looks more intently at one sex than the other. Women disproportionately experience the urgency of maintaining new life, as well as nature's cyclical processes of violence and decay, while men disproportionately experience the thrill of creating life, the drama that is the marking out of a singular life story in which narrative time ${ }^{16}$ breaks in on cyclical time. Both of these faces of time and the tension between them are integral to the human condition and to each individual life, whether male or female. While the division between them lends itself to a division of 
interests between the sexes, it does not cause such a division determinatively. And while a division of interests might become causally entangled with a division of power, it is not in a simple causal chain with such divisions.

This becomes more clear as we leave Beauvoir's discussion of biology behind and attend to her description of the temporality of housework. ${ }^{17}$ On my reading of Beauvoir, where women are confined to immanence, the shape of cyclical time diffracts, for women, into repetition. Beauvoir gives an account of this diffraction without noting that she is doing it. She speaks of cyclical time as "reassuring" for the housewife: "In the garden the seasons register their reassuring cycles in the growth of edible vegetables; each year the same springtime with the same flowers foretells the return of immutable summer, of autumn with its fruits identical with those of all other autumns" (Eng. 449, Fr. Vol. II, 257, translation amended). While Beauvoir writes, in this and other passages, of the cyclical time of nature and the repetitive time of women's reproductive labor as if they were equivalents, she is grappling with a relation that is more complex. Cyclical time is not repetitive, in any strict sense. Each spring is lived as both a similar and a unique event, each winter is both defined by and stands out against the background of other winters. Each birth, each death, is a radically singular occurrence, even as it is profoundly similar to other deaths and births. Beauvoir seems to acknowledge this at some points, writing, for example, that "time simultaneously creates and destroys" (Eng. 45I, Fr. Vol. II, 265), The point is that once women are confined to immanence, cyclical time is no longer cyclical in the full sense. The cyclical time of nature diffracts into the repetitive time of life lived as a relative being, whose labor is exploited by others. Here the tension between cyclical time and narrative time is broken in the singular life of a woman, and she lives without recourse to narrative time except derivatively, through her relation to a man. "There are few tasks more like the torture of Sisyphus than housework; day after day, the plates must be washed, the furniture polished, the laundry mended -all of which will once again be dirty, dusty and torn tomorrow. The housewife wears herself out turning in circles: she makes nothing, simply perpetuates the present” (Eng. 45I, Fr. Vol. II, 263, alternate translation).

The diffraction of cyclical time into repetition has severe consequences. "Washing, ironing, sweeping, ferreting out rolls of lint from under wardrobes-all this halting of decay is also the denial of life; for time simultaneously creates and destroys, and only its negative aspect 
concerns the housekeeper" (Eng. 45I, Fr. Vol. II, 265, my emphasis). The suffering and the injustice in the disproportionate distribution of reproductive labor to women is not caused by the division between the two faces of time that is a general feature of human existence, but it is nourished at the site of the split. We might say that the injustice is parasitically entangled with and takes root in the primordial scission in time, which is one of the most general, irrevocable, features of human existence. This entanglement diffracts the cyclical time of nature into the temporality of oppression.

This claim, that structures of injustice are parasitically entangled with general features of human existence, even those that seem most "natural," i.e. most rooted in human biology and our necessary metabolism with the earth, is at the very heart of what I take to be Beauvoir's greatest contribution to feminist thinking. While never spelling it out for us, Beauvoir's method allows her to sketch an account of these entanglements. If this is the case, then this particular "founding moment" of feminist thought is not characterized by "nature skepticism" in any simple way, but by a kind of persistent acknowledgement and sorting out of the entanglements of the natural with the instituted, a description of how something of human making nourishes itself at the trough of nature.

A poignant contemporary example might, in its stark literality, make the stakes of Beauvoir's contribution even more clear. Here I am referring to Eva Maria Simms remarkable philosophical study of the placenta in relation to the process of biomagnification, in which toxins ingested at the bottom of the food chain are concentrated at the top. The top of the food chain is generally imaged as an adult male human, but this is misleading. Simms notes, "when I actually imagine a woman at the top of the food-chain... I see her body not as self-owned and closed off; rather, the female body is open, a conduit for the next generation. There is no hierarchical top of the food-chain: woman herself becomes food for her young. She is a link and an integrated element in the chain of those who eat and are eaten" (Simms 2008, 2). In 2004, a surge of media interest in the increasing toxicity of human breast milk resulting from environmental toxins and toxins in the food and water supply caught Simm's attention. Breast feeding both passes these toxins on to the infant and reduces the toxins in the mother's own system, but this process of exchange starts even before birth through the literal intermediary space of the placenta. "The infant's uterine eco-system is embedded within the larger field of 
the mother's bodily environment. Contaminants in the mother's air, food, and water pass the placental barrier: mercury, lead, PCB's, pesticides, and other toxic chemicals lead to birth defects, premature birth or long-term impairments of physical and psychological functioning of the child” (15). Simms, building on work by Merleau-Ponty, begins to develop a "psychoanalysis of nature" through examining "the intersection between human being and the realm of nature at the level of the organism" (20). Our "metabolism with the earth" starts in and as part of the body of the mother, in fact '"the flesh/the mother' is the ground where the entwining of the instituted with the uninstituted, the customary with the wild, and the discursive with the silent can be found," Simms writes (20).

Of course neither pregnancy nor breast feeding are universal features of female existence, but the capacity for these is limited, at present, to (some/most) humans who are female, and to an extended but limited period of their lives. Perhaps more significantly, becoming a distinct being in and coming into the world through a female body is, at present, a universal feature of human existence. Having had one's life maintained, in its earliest moments, by a female body, is a history every human shares. Precisely here, in this most indisputably natural place, at the split between the faces of time Beauvoir described, at the scission that is natural sexual difference, a nature that is irreducible to and excessive to human making (we neither choose nor design this path into the world) is intricately intertwined with and marked by humanly instituted processes. ${ }^{18}$

While this is, perhaps, an overly literal example, it serves to wake us up to the process of entangling at the shifting, messy, blurred demarcation between nature and culture. Beauvoir's method pushes us to notice these entanglements, to begin to sort them out without allowing ourselves to reduce one side to the other, to either deny the significance of the natural or to sink comfortably into the succor of a determinatively causal account of our relation to it. At one founding moment of contemporary feminist thinking, then, deconstructive and descriptive engagements with the question of nature, far from being opposed, are co-necessary features of feminist thought.

What bothers me about the splitting of feminism between the champions of originary sexual difference and the critics of sexual difference, is that this seems to represent feminism's version of the common human unwillingness or incapacity to endure the ambiguity of the 
human condition. The temptation is always to flee the ambiguity by reducing it, by making nature into consciousness (and I think the critics of sexual difference do this by making nature a product of discourse or material practices), or by making consciousness into nature (and I think the champions of sexual difference do this by claiming women's ways of knowing or women's ways of writing are rooted in an originary, bodily difference).

But what do we lose here? Most significantly, feminist accounts of nature, whether critical or affirming, tend to be ghettoized around the question of sexual difference. For Beauvoir, the question of sexual difference was rooted in the ambiguity of human existence, the particular conditions of existence that characterize a creature who is both of nature and consciousness of nature. The oppression of women, she taught us, was parasitic on and entangled with that ambiguity. She understood the question of sexual difference in the broader tensions between the finite and the infinite, immanence and transcendence, cyclical time and narrative time, our metabolism with the earth and our drive to move beyond that metabolism and do things that will last. "In life," she wrote, "there are two conjoined movements; it only maintains itself when it exceeds itself; it only exceeds itself on the condition that it maintains itself; these two movements always fulfill themselves together, it is abstract to try to separate them" (Eng. 13; Fr. Vol. I., 49; translation amended). What Beauvoir shows us is that the problem of nature, for women, isn't reducible to the problem of sexual difference, meaning also that the problem of sexual difference isn't reducible to the problem of sexual difference. What I am claiming here is that at the founding moment of contemporary feminist philosophy in the west, the question of nature was posed as both an ontological question and a political question. Beauvoir exposed the entanglement of the ontological with the political. "Our task," she wrote, "is to know how nature has been taken up in [woman] in the course of history" (Eng. 37; Fr. Vol. I, 79; translation amended). The confinement of women to the realm of immanence, the assignment of women to the maintenance of life, to the holding together of time (Eng. 63; Fr. Vol. I, 25), are the political forms that feed on the existential condition. In order to even ask the question of sexual difference one had to ask questions about the finite and the infinite, the cyclical and the narrative, our metabolism with the earth and our capacity to extend ourselves into spaces that exceed that metabolism. 
The question of sexual difference, for Beauvoir, opened out onto the complex tension and relation between humans and nature. This constituted a radical upheaval precisely because the use of "nature" as justification for women's oppression historically and today, fastens on and becomes obsessed with questions of natural sexual difference, and diverts all attention away from the common human condition that defines our relation to nature. When feminists are unwilling or unable to endure the ambiguity of the human condition, to suffer that ambiguity, we tend to fasten on and become obsessed with the very same question, and we radically reduce our field of engagement with the question of nature. We implicitly accept our confinement within the boundaries of natural sexual difference, whether as the object of our enthusiasm or the object of our criticism.

\section{Conclusion}

At a time like the one we are living in, when strange and short-sighted ways of structuring our metabolism with the earth have brought us to a new point of crisis in that relation, we can ill afford such a reduced field of engagement. Soper's claim, that "the inaugural move of feminism, in fact, was the challenge it delivered to the presumed 'naturality' of male supremacy," that "Feminism... gets off the ground through a deconstructive move whose effect

is to expose the discursive ... function of 'nature' in endowing with the seal of necessity what in reality is a matter of convention" (Soper 1995, 121), is not wrong, but it is incomplete. A reconsideration of just this one inaugural event of feminism, reveals that it cannot be adequately characterized only by attending to its deconstructive side. Beauvoir exposes both the justificatory appeal to nature and the entanglement of power with nature, how power feeds on nature, and how we live in necessary tension with nature... and this nature is not merely a discursive effect.

The question of nature is so central to feminist thought because feminist thinking is the thinking of a social movement that aims at removing the millstone tied round women's necks. This puts feminists in a tense relation to the natural. Beauvoir's genius was to think this historical tension along with the ontological tension that it feeds on, to broaden the question of sexual difference into the question of nature as a central aspect of the human condition. Feminists need to return to this founding moment, and try to grasp it in its complexity, to 
endure the ambiguity, if we are to work our way through the contemporary divide in feminism over the question of sexual difference, and to address the question of nature in a way that is more fully relevant to the challenges facing all of us in our contemporary world. 
${ }^{1}$ The world's largest funeral home chain.

2 Beauvoir wrote, even in The Second Sex, with "generic" masculine pronouns. I've taken the liberty of changing those here, since stylistic conventions have changed, and since Beauvoir clearly meant this passage to refer to all humans.

${ }^{3}$ For many or most women this mandate might be better described as "triple" since colonizers habitually locate colonized peoples, women and men, in the realm of nature, as well as locating women of their own nation or race in that sphere. The literature is full of direct comparisons (see references to these in Kaplan and Rogers, Gene Worship, 2003, pp. 32-36).

${ }^{4}$ Let's not forget that the very inauguration of the symbolic for both Levi-Strauss and Freud was founded in the exchange of women by men, women being the natural resource that enabled men to turn human life from nature to culture, from things to representations, from biology to language. Women are the transition, for men, from natural object to symbol.

${ }^{5}$ These efforts take a number of forms, I will mention only a few here. A resurgent interest in feminist phenomenology is characterized by a healthy unwillingness to "choose" between nature and culture. See Heinamaa (1996, 2003); Moi (200I). The work of feminist physicist and philosopher of science, Karen Barad, is extremely promising. Barad sets out to develop "a posthumanist performative account" which will avoid "cementing the nature-culture dichotomy into its foundations, thereby enabling a genealogical analysis of how these crucial distinctions are materially and discursively produced (2007, 32)." Though I find her work inspiring, and have drawn on it in this essay, I worry that Barad ends up reducing culture to nature in her "agential realist" account, in which agency seems to become something like "dynamism;" this allows Barad to put human agency and other sorts of agency into one big melting pot. Also promising is the recent work of Linda Alcoff, I recommend "The Metaphysics of Gender and Sexual Difference,” (2006). Lesley Rogers' and Gisela Kaplan's work in science and philosophy of science (Rogers 200I; Rogers and Kaplan 2003) are much more nuanced than the genefundamentalist's accounts that they criticize. And of course much ecofeminist work has cultivated a new non-reductive sensibility about the relation between women and nature, Soper is a good example here (1995).

${ }^{6}$ Albeit in a circular way, arguing that sex differences are attributable to "the simple fact that males and females in ancestral populations faced very different obstacles to reproduction" (2000, 3I) which amounts to saying "sex differences are attributable to sex differences," since sex differences have already been defined as a division of labor in reproduction.

${ }^{7}$ See Kaplan and Rogers: Gene Worship: Moving Beyond the Nature/Nurture Debate over Genes, Brain, and Gender.

${ }^{8}$ Interestingly, this position is now emerging in some feminist thought explicitly, though in a very different form, even as some evolutionary biologists claim to have given it up. Those who are working to end sex-assignment surgery on infants and toddlers with ambiguous genitalia 
argue that the body itself, its capacities for both pain and pleasure, give us at least enough moral guidance before a new person can speak to warrant postponing such surgeries until the person whose body is being cut can decide what those body parts they are about to lose mean to them (see Dreger 2006). Feminist care ethicists claim that the vulnerability of the developing, disabled, or aging body make strong moral claims on us (Kittay 1999). In Judith Butler's recent ethical work, she also locates the moral force for claims for nonviolence in the universal vulnerability of the human body (2004). In my own work, I understand our metabolism with the earth to have strong ethical force in relation to how we deal with both the environment and one another (Mann 2006).

${ }^{9}$ So as not to mislead the reader unfamiliar with Soper's work, I should say here that Soper is also complicating the division between "nature skeptical" and "nature endorsing" accounts in her work, not simplifying, and her work is key to what l'm doing here.

${ }^{10}$ When not otherwise noted, I am using the infamous Parshley translation of The Second Sex, the only published translation in the English language. Because the translation is so notoriously misleading, l've included the volume and page numbers for the French Folio edition as well. When l've amended a translation, I note this. I sometimes use alternate translations, prepared for my own use, of both the "Introduction" and "The Married Woman" chapters, the first prepared by my colleague Beata Stawarska and I, the second by a graduate student who I was able to hire for the purpose thanks to a grant from the University of Oregon College of Arts and Sciences. When I cite these alternate translations I have noted this as follows: "alternate translation." For readers not familiar with the translation issues I recommend Margaret Simons. "The Silencing of Simone de Beauvoir: Guess What's Missing from The Second Sex." Women's Studies International Forum 6/5 (1983), 559-64), and Toril Moi. "While We Wait: Notes on the English Translation of The Second Sex.” The Legacy of Simone de Beauvoir, ed. by Emily R. Grosholz, (Oxford \& New York: Oxford University Press, 2004). Apparently, a new translation is now in the works, though the publishers have elected not to do a scholarly edition and the translators are not themselves philosophers. See "Bookforum" in Artforum, Apr/May 2007.

${ }^{11}$ See Heinamaa, 2003, p. 74 for a discussion of these criticisms. Gatens argues that "woman emerges from [Beauvoir's] study as biologically disadvantaged” (Gatens 1991, 52). Léon puts it this way, "Breasts and buttocks are [for Beauvoir] fleshy proliferations that, in the fullness of their gratuitous immanence, dread mirrors and caresses. While she equates sex with an animal function of brutal reality, she defines female physiology in terms of inertia, passivity... In these horrifying passages, which inform more on the neuroses of their author than on a presumed feminine essence, nature is identified with woman who is, in turn, identified with the disgust generated by her sexual organs"(Léon 1995, 143-144). Chanter says that Beauvoir "ascribes a purely negative connotation to the ways in which women differ from men" (Chanter 1995, 4950).

12 How "transcendence" should be understood in Beauvoir's work is a point of contention. Most Beauvoir scholars working out of a phenomenological tradition reject this reading of "transcendence" as insufficiently rooted in the philosophical tradition in which Beauvoir was trained and insufficiently attentive to nuances in Beauvoir's own work. 
${ }^{13}$ As Heinamaa puts it, "The nature of the subject is essentially ambiguous, paradoxical. The subject is a constant indecision between inwardness and externality, immanence and transcendence, finitude and the infinite. The paradox cannot be resolved; it can only be endured and executed in various different ways" (2003, II). As Veltman puts it, "bad faith is expressed either as a denial of our transcendence or as a denial of our immanence" (85-86). See also Scarth, 2004.

${ }^{14}$ In "The Notorious Contradictions of Simone de Beauvoir," Deutscher argues convincingly that we should pay attention to what the "contradictions" are doing rather than try to resolve them.

${ }^{15} \mathrm{I}$ am borrowing this language from the work of Karen Barad without necessarily staying strictly true to her use and development of these terms.

16 "Narrative time" is my formulation, influenced by Hannah Arendt, not Beauvoir's.

${ }^{17}$ For an important discussion of the centrality of housework to Beauvoir's understanding of oppression, see Veltman, 2004.

${ }^{18}$ I am leaving out equally interesting "markings" such as those created by amniocentesis or ultrasound, fetal surgery, or other more direct and conscious interventions. 